\title{
Uji Diagnostik Indeks Darah dan Identifikasi Molekuler Karier Talasemia 6 pada Pendonor Darah di Banyumas
}

\section{Diagnostic Test of Blood Index and Molecular Identification of 6 Thalassemia Carrier among Blood Donor Subjects in Banyumas}

\author{
Ariadne Tiara Hapsari', Lantip Rujito ${ }^{2}$ \\ ${ }^{1}$ Departemen Ilmu Kesehatan Anak Rumah Sakit Margono Soekardjo Purwokerto \\ ${ }^{2}$ Laboratorium Riset Biologi Molekuler Fakultas Kedokteran dan IImu IImu Kesehatan Universitas Jenderal Soedirman \\ Purwokerto
}

\begin{abstract}
Talasemia menempati kelainan genetik yang paling umum di seluruh dunia dengan prevalensi karier talasemia di Indonesia adalah sekitar 3-10\%. Banyumas merupakan salah satu wilayah yang menyumbang angka prevalensi penderita talasemia yang cukup besar. Salah satu perangkat dalam program pencegahan terpadu adalah memastikan diagnosa molekuler pada tahap skrining sesuai dengan mutasi lokal. Tujuan dari penelitian adalah untuk mengetahui nilai uji diagnostik indeks darah dan karakterisitik mutasi talasemia 8 pada pendonor darah yang dicurigai karier talasemia. Subjek penelitian adalah 183 pendonor darah rutin pada PMI Banyumas. Skrining awal menggunakan indeks darah MCV, MCH, dan Hemoglobin elektroforesis. Karakteristik molekuler dilakukan dengan teknik PCR-RFLP dan teknik ARMS. Hasil penelitian menunjukkan bahwa MCV memiliki nilai sensitivitas $81,3 \%$, dan spesifisitas $95,8 \%$ sedangkan $\mathrm{MCH}$ menunjukkan sensitivitas sebesar $80 \%$ dengan spesifisitas $97,5 \%$. Mutasi IVS-1 nt 5 (G>C) merupakan mutasi tersering disusul dengan HBE (codon 26) dan IVS1 nt 1(G>T).
\end{abstract}

Kata Kunci: Identifikasi molekuler, indeks darah, karier talasemia

ABSTRACT

Thalassemia occupies the most common genetic disorder worldwide. Prevalence of thalassemia carrier in Indonesia is around 3-10\%. Banyumas is one of several areas that accounts for high prevalence of thalassemia patients. One of the tools in an integrated prevention program is to ensure the molecular diagnosis at screening stage is in accordance with the local mutation. The aim of the study is to find out the value of diagnostic testing of blood and characteristic index $b$ thalassemia mutations in blood donors suspected as thalassemia carrier. The research subjects were 183 regular blood donors at Red Cross Banyumas. The initial screening used MCV blood index, MCH, and Hemoglobin electrophoresis. Molecular characteristics were performed using PCR-RFLP and ARMS techniques. The results show that MCV has a sensitivity value of $81,3 \%$ and specificity $95,8 \%$ while MCH shows a sensitivity of $80 \%$ with specificity $97,5 \%$. Mutation IVS-1 nt $5(G>C)$ is the most frequent mutation followed by HBE (codon 26) and IVS1 nt 1 (G>T).

Keywords: Blood index, molecularidentification, thalassemia carrier

Jurnal Kedokteran Brawijaya, Vol. 28, No. 3, Februari 2015; Korespondensi: Lantip Rujito. Laboratorium Riset Biologi Molekuler, Fakultas Kedokteran dan IImu IImu Kesehatan Universitas Jenderal Soedirman Purwokerto, Jl. Gumbreg No. 1, Purwokerto 53146 Tel. (0281) 622022 Fax.(0281)624990Email:I.rujito@unsoed.ac.id 


\section{PENDAHULUAN}

Talasemia diartikan sebagai sekumpulan gangguan genetik yang mengakibatkan berkurang atau tidak ada sama sekali sintesis satu atau lebih rantai globin. Talasemia menempati kelainan genetik yang paling umum di seluruh dunia. Sebanyak $4,83 \%$ dari populasi dunia membawa globin varian, termasuk didalamnya 1,67 persen populasi yang heterozygous untuk $\alpha$ talasemia dan $\beta$ talasemia (1). Prevalensi talasemia di Indonesia sekitar $3-10 \%$ (2). Data menunjukkan bahwa dari 250 ribu populasi penduduk ditemukan sekitar 2.500 kasus baru setiap tahunnya. Saat ini terdapat kira-kira 5.000 pasien yang masih hidup. Sebanyak 2.500-3.000 pasien tersebut lahir di Indonesia. Data ini menunjukkan penderita talasemia sebelum umur 6 tahun sudah banyak yang meninggal di rumah (3).

Banyumas adalah daerah dengan pertambahan penderita talasemia yang cukup pesat dengan jumlah penderita melebihi angka 250. Data menunjukkan penambahan kasus adalah 3-7 penderita pertahun atau penderita tiap tahunnya atau 4,76\% -11,50\% tiap tahunnya dari jumlah kasus sebelumnya (4). Karakteristik wilayah menunjukkan masih banyak daerah terisolir dengan banyak daerah pegunungan. Beberapa penderita menunjukkan kedekatan keluarga satu sama lain serta adanya satu keluarga dengan beberapa anak talasemia.

Saat ini progam pencegahan sedang digalakkan oleh Pusat Kajian Talasemia Banyumas bekerjasama dengan Palang Merah Indonesia (PMI), Yayasan Talasemia Indonesia (YTI), Universitas Jenderal Soedirman (UNSOED), dan Pemerintah Daerah. Salah satu perangkat dalam program pencegahan terpadu adalah memastikan uji penyaring yang efektif berdasarkan presentasi lokal. Uji hematologis dengan indeks darah berupa mean corpuscular volume (MCV) dan mean corpuscular hemoglobin ( $\mathrm{MCH}$ ) selama ini masih menjadi ujung tombak skema penyaringan. Meskipun demikian data diberbagai daerah dapat menunjukkan nilai cut off point yang berbeda. Beberapa tempat di Eropa nilai MCV $\leq 70 f l$ dan $\mathrm{MCH} \leq 25 \mathrm{pg}$ menjadi dasar pada daerah nilai yang di anut (5). Dengan menggunakan nilai sejenis, pada daerah lainnya dapat meloloskan pembawa sifat talasemia $B$ (6). Di Indonesia sendiri kajian Health Technology Assesment (HTA) merekomendasikan $\mathrm{MCV} \leq 80 \mathrm{fl}$ dan $\mathrm{MCH} \leq 27 \mathrm{pg}$ serta nilai $\mathrm{HbA}_{2} \geq 3,5 \%$ sebagai perangkat skrining (7). Pemeriksaan yang sesuai dengan nilai indeks hematologis lokal dapat menyaring pembawa sifat dengan hemat, sebelum dilanjutkan dengan pemeriksaan hemoglobin elektroforesis yang jauh lebih mahal.

Untuk menilai paramater hematologis lokal sebagai nilai skrining lokal perlu dilakukan kajian terkait dengan dengan hal tersebut. Selain itu saat ini mutasi yang terjadi pada gen globin $B$ dan $\alpha$ tercatat lebih dari 200 jenis mutasi (8). Namun demikian, terdapat kecenderungan etnis dan geografi yang berbeda pada jenis-jenis mutasi tersebut. Pengetahuan tentang aspek molekuler sesuai dengan etnik lokal pada perangkat uji skrining sangat penting untuk konseling genetik pada keluarga serta diharapkan protokol pencegahan dapat dilaksanakan secara efektif dan efisien.

Selain fakta tersebut, secara umum pembawa sifat atau karier talasemia tidak akan menunjukkan gejala klinis dan dapat hidup layaknya individu normal (9). Data ini menunjukkan bahwa para pendonor darah tersebut dapat sekaligus sebagai karier untuk talasemia. Pembawa sifat yang secara rutin mendonorkan darahnya dapat mengganggu sistem eritropoiesis yang dapat berakibat sistemik. Untuk itu pemeriksaan uji skrining pada para pendonor menjadi penting. Berdasarkan latar belakang tersebut dilakukan penelitian ini untuk mengetahui nilai uji diagnosis indeks hematologis, prevalensi karier talasemia, serta mengetahui mutasi talasemia $b$ pada pendonor darah di Banyumas.

\section{METODE}

Penelitian menggunakan studi cross sectional dengan subjek yang mengikuti skrining talasemia menggunakan perangkat nilai hematologis sebanyak 183 subjek diseluruh wilayah Banyumas. Sampel diambil menggunakan proporsional random sampling yang mewakili semua wilayah di Banyumas. Pemeriksaan indeks hematologis dan hemoglobin elektroforesis dilakukan di Laboratorium Klinik RS Margono Soekardjo Purwokerto. Isolasi dan DNA dilakukan di Laboratorium Riset Fakultas Kedokteran dan IImu Kesehatan (FKIK) Universitas Jenderal Soedirman (Unsoed) dan Laboratorium Riset Terpadu Unsoed. Nilai indeks hematologis yang diukur dalam penelitian ini adalah $\mathrm{Hb}$ dalam satuan $\mathrm{g} / \mathrm{dl}$, MCV dalam satuan $\mathrm{fl}, \mathrm{MCH}$ dalam satuan pg. Nilai indeks hematologis diukur menggunakan automatic machine XP 2000. Kecurigaan karier talasemia ditentukan dengan rujukan $\mathrm{MCV}<80 \mathrm{fL}, \mathrm{MCH}<27 \mathrm{pg}$ dan $\mathrm{HbA}_{2}>3,5 \%$. Jenis mutasi pada gena globin $B$ sesuai dengan data base yang terdapat di A Database of Human Hemoglobin Variants and Talasemias (http://globin.bx.psu.edu/hbvar/ menu.html). Identifikasi mutasi menggunakan teknik ARMS sesuai dengan yang dijelaskan pada referensi rujukan $(10,11)$.

\section{HASIL}

Sebanyak 183 pendonor, seluruhnya merupakan pendonor darah tidak rutin, didominasi oleh pria yang jumlahnya mencapai 147 orang (82\%). Sebanyak 22 sampel dari jumlah subjek memiliki nilai $\mathrm{MCV}<80 \mathrm{fL}, \mathrm{MCH}$ $<27 \mathrm{pg}$ dan $\mathrm{HbA}_{2}>3,5 \%$. Karaktersitik indeks darah dari subjek tersebut disajikan pada Tabel 1. Hasil pemeriksaan laboratorium menunjukkan bahwa secara umum kelompok yang dicurigai karier talassaemia- 6 memiliki nilai rerata $\mathrm{Hb}, \mathrm{MCV}, \mathrm{MCH}$, dan $\mathrm{HbA}$ yang lebih rendah dari kelompok pendonor normal dan kelompok karier memiliki nilai indeks $\mathrm{HbA}_{2}$ dan $\mathrm{HbF}$ yang lebih tinggi dari kelompok normal. Beberapa individu memiliki gambaran klasik karier talasemia 6 dengan $\mathrm{HbA} 2 \geq 3,5$ (12).

Tabel 1. Perbandingan nilai index darah karier talasemia dan normal

\begin{tabular}{|c|c|c|c|}
\hline \multirow{2}{*}{$\begin{array}{l}\text { Index } \\
\text { Darah }\end{array}$} & \multicolumn{2}{|c|}{$\begin{array}{c}\text { Nilai Mean dan Standard } \\
\text { Deviasi }\end{array}$} & \multirow{2}{*}{$\begin{array}{c}\text { T test } \\
\text { ( } p \text { value) }\end{array}$} \\
\hline & $\begin{array}{c}\text { Karier } \\
\text { Talasemia }\end{array}$ & $\begin{array}{l}\text { Normal } \\
\text { Proband }\end{array}$ & \\
\hline HB & $13( \pm 1,82)$ & $13,6( \pm 1,56)$ & 0,89 \\
\hline MVC & $77,2( \pm 5,67)$ & $87,7( \pm 3,68)$ & 0,021 \\
\hline $\mathrm{MCH}$ & $24,7( \pm 2,3)$ & $29,8( \pm 1,5)$ & 0,008 \\
\hline HbA2 & $4,6( \pm 1,1)$ & $2,8( \pm 0,23)$ & 0,00 \\
\hline $\mathrm{HbF}$ & $4,3( \pm 10,13)$ & $0,16( \pm 0,39)$ & 0,003 \\
\hline
\end{tabular}

Indeks darah pada kelompok karier menunjukkan konsistensi terhadap kriteria umum. Untuk nilai HbA2 
pada beberapa individu dengan nilai MCV dan $\mathrm{MCH}$ yang rendah memiliki nilai $<3,5 \%$. Gambaran nilai MCV dan atau $\mathrm{MCH}$ yang rendah akan tetapi $\mathrm{HbA2}$ normal, menunjukkan bahwa individu tersebut dapat dicurigai sebagai pembawa sifat talasemia $\alpha(13)$.

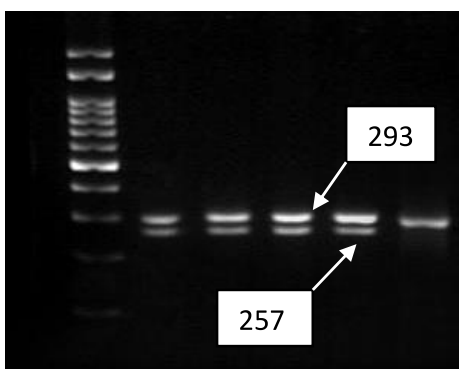

Gambar 1. Pemeriksaan DNA IVS1 nt 5 dengan teknik PCRRFLP

Keterangan: Alel normal memiliki 293 bp, dan alel IVS1-5 memiliki 257 dan $36 \mathrm{bp}$

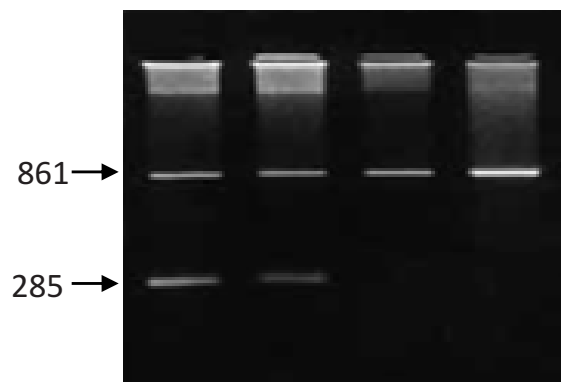

Gambar 2. Hasil ARMS mutasi IVS1-5.

Keterangan: Pita muncul dengan produk 285bp menunjukkan mutasi IVS1-5, pita 861bp merupakan kontrol primer

Pemeriksaan DNA adalah kelanjutan setelah melalui pemeriksaan penunjang awal, mulai dari pemeriksaan indeks darah dan $\mathrm{Hb}$ elektroforesis (14). Pemeriksaan DNA menggunakan teknik ARMS memiliki keunggulan cepat, murah, dan dapat dikerjakan serentak. Pemeriksaan tersebut memiliki keterbatasan, tidak semua jenis alel dapat diperiksan dengan metode ARMS (11). Selain itu pemeriksaan dapat juga dilakukan dengan teknik PCRRFLP dengan menggunakan enzim yang dapat mengenali perubahan basa di alel yang dikehendaki. Hasil pemeriksaan DNA dengan dua metode tersebut disajikan pada Gambar 1 dan 2.

Tabel 2 menyajikan pemeriksaan terhadap 183 probandus secara lengkap. Hasil menunjukkan mutasi karier talasemia di Banyumas sebesar 8,74\%. Terdapat tiga macam mutasi yaitu IVS1-nt5 (G>C), IVS1-nt1 (G>T), dan CD26 (G>C) (HBE), dengan mutasi terbanyak adalah IVS1$n+5(G>C)$.

Tabel 2. Jenis mutasi karier talasemia di Banyumas

\begin{tabular}{lr}
\hline Jenis Mutasi & Prosentase \\
\hline IVS1-nt5 (G>C) & $6,04 \%$ \\
IVS1-nt1 (G>T) & $0,5 \%$ \\
CD26 (G>C) (HBE) & $2,20 \%$ \\
\hline
\end{tabular}

Skrining menggunakan paramater indeks darah MCV dan $\mathrm{MCH}$ menunjukkan bahwa sensitivitas MCV dengan cut off point $<80 \mathrm{fl}$ adalah $81,3 \%$, spesifisitasnya adalah $95,8 \%$. Pemeriksaan $\mathrm{MCH}$ pg dengan cut off point $<27$ menunjukkan sensitivitas sebesar $80 \%$ dengan spesifisitas $97,5 \%$. Untuk mengetahui cut off point MCV dan MCH dari nilai asli dilakukan analisis kurva ROC. Dengan mengunakan kurva ROC dapat diketahui bahwa nilai terbaik dari masing masing parameter adalah MCV: 84fl dengan sensitivitas $77 \%$, spesifisitas $85 \%$ dan area di bawah kurva (UCA): 91,2\%. MCH mempunyai nilai yang tidak jauh berbeda dengan MCV yaitu; $\mathrm{MCH}$ : 27,06fl dengan sensitivitas $96 \%$, spesifisitas $85 \%$ dengan area di bawah kurva $91,6 \%$.

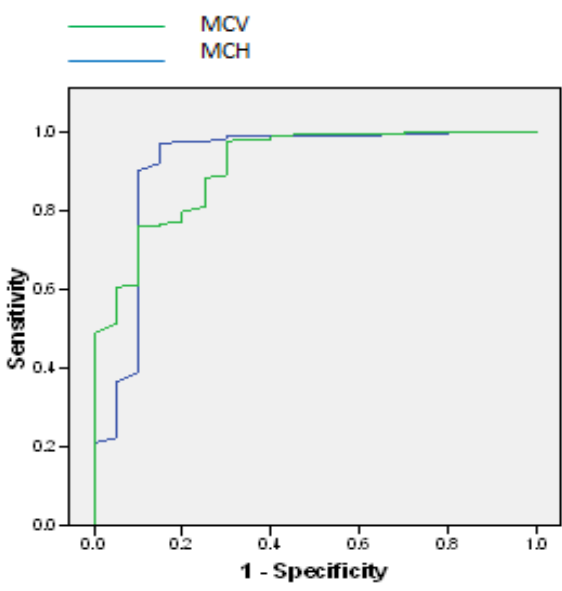

Gambar 3. Kurva ROC MCV dan MCH terhadap gold standar DNA

Keterangan: Nilai undercurve area MCV sebesar $91,2 \%$ untuk point 84 $\mathrm{fl}$, dan $\mathrm{MCH}$ sebesar $91,6 \%$ untuk point 27,06 pg

\section{DISKUSI}

Pemeriksaan skrining untuk mengetahui pembawa sifat talasemia merupakan bagian integral dari upaya pencegahan di suatu wilayah. Perekaman data primer tentang epidemiologi karier talasemia di suatu tempat menjadi langkah awal yang harus dilakukan instansi yang terlibat dalam upaya pencegahan tersebut. Pengetahuan tentang prevalensi talasemia dan juga hemoglobinopati tersebut dapat digunakan untuk merumuskan langkah strategis sesuai dengan temaun karakterisitik karier di daerah tersebut.

Penelitian ini merupakan bagian dari tahapan dalam kerangka pencegahan penyakit talasemia yang sedang digalakan oleh Tim Peneliti Talasemia di Banyumas. Data menunjukkan bahwa pembawa sifat atau karier talasemia di Banyumas adalah 8\%. Angka ini termasuk dalam kelas yang tinggi jika dibandingkan rata-rata pembawa sifat talasemia di Indonesia yang sebesar 3-10\% (2).

Penentuan panel pembawa sifat didasarkan pada pemeriksaan hematologis yang paling sederhana berupa apusan darah, berlanjut ke pemeriksaan indeks hematologis, penentuan fraksi hemoglobin, dan sebagai gold standard adalah pemeriksaan DNA. Penilaian MCV dan $\mathrm{MCH}$ sebagai nilai indeks darah yang digunakan, mempunyai nilai yang bervariasi antar negara. Indonesia mengacu pada protokol ICHS yang memberlakukan nilai 
indeks darah $\mathrm{MCV}<80 \mathrm{fl}$, dan $\mathrm{MCH}<27$ pg untuk menyaring pembawa sifat talasemia. Beberapa negara menggunakan parameter yang berbeda terutama MCV seperti di Sardinia menggunakan batasan $<78 \mathrm{fl}$, dan Hongkong dengan batasan MCV <75fl (6). Penelitian Weatherall bahkan merekomendasikan nilai MCV <70fl sebagai kriteria skrining karier di Sardinia (5).

Kelompok karier talasemia- $b$ memiliki nilai rerata $\mathrm{Hb}$ sebesar $13 \mathrm{~g} / \mathrm{dL}$, sedangkan kelompok normal memiliki nilai rerata $\mathrm{Hb}$ yang lebih tinggi, yaitu sebesar $13,6 \mathrm{~g} / \mathrm{dL}$. Secara umum hasil ini sesuai dengan penelitian terdahulu yang menyatakan bahwa secara statistik tidak menunjukan perbedaan signifikan antar kelompok normal dan kelompok karier $(9,15)$. Walaupun demikian, kadar $\mathrm{Hb}$ rata-rata pada karier talasemia sedikit lebih rendah dari pada individu normal $(8,16)$.

Parameter indeks darah dalam penelitian ini menunjukkan bahwa dengan cut off point MCV $<80 \mathrm{fl}$ ditemukan nilai sensitivitas $81,3 \%$, dan spesifisitasnya adalah $95,8 \%$. Sebaliknya MCH pg dengan cut off point $<27$ menunjukkan sensitivitas sebesar $80 \%$ dengan spesifisitas $97,5 \%$. Nilai diagnosis dari parameter ini menunjukkan kualitas yang baik dengan nilai di atas $80 \%$. Indeks darah telah digunakan secara luas dalam penentuan skrining pembawa sifat talasemia di seluruh dunia. Dengan menggunakan parameter indeks darah ini artinya dari 100 orang dengan karier talasemia akan dapat disaring kurang lebih 80 orang. Tingkat spesifisitas yang tinggi juga menunjukkan kekuatan nilai diagnosis dari parameter ini untuk menyingkirkan diagnosis selaian talasemia.

Perbedaan variasi dari nilai indeks $\mathrm{MCV}$ dan $\mathrm{MCH}$ disebabkan oleh perbedaan variasi berat dan ringannya jenis mutasi talasemia yang ditemukan di setiap bagian (9). Beberapa mutasi bersifat khas untuk daerah tersebut sedangkan mutasi lain terjadi di negara lain. Untuk daerah dengan jenis mutasi talasemia $B$ umumnya menunjukkan nilai MVC dan $\mathrm{MCH}$ yang sangat rendah, kurang dari $70 \mathrm{fl}$, dan 25pg sehingga beberapa negara menggunakan paramater $<70 \mathrm{fl}$ dan $<25 \mathrm{pg}$ (17).

Indonesia dengan tingkat variasi mutasi HbE dan IVS1, maka dengan nilai parameter yang rendah ini akan menurunkan nilai sensitivitas dan spesifisitas dari indeks hematologis ini. Untuk itu keputusan untuk mengambil nilai $<80 \mathrm{fl}$ dan $<27 \mathrm{pg}$ sesuai dengan kondisi mutasi di Indonesia (7). Hal ini juga diperkuat dengan penelitian ini bahwa dengan nilai indeks tersebut mempunyai nilai diagnostik yang sangat baik.

Parameter $\mathrm{HbA}_{2}$ menjadi tolak ukur penyaring kedua untuk mendeteksi pembawa sifat talasemia. Penelitian-

\section{DAFTAR PUSTAKA}

1. Weatherall DJ. Thalassemi as a Global Health Problem: Recent Progress Toward its Control in the Developing Countries. Annals of the New York Academy of Sciences. 2010; 1202(1): 17-23.

2. Sofro AS. Molecular Pathology of Beta-Talasemia in Indonesia. The Southeast Asian Journal of Tropical Medicine and Public Health. 1995: 26 (Suppl1): 221224.

3. Lanni F, Gani RA, Widuri, Rochdiyat W, Verawaty B, Sukmawati, dkk. B-Thalassemia and Hemoglobin-E penelitian menunjukkan bahwa nilai $\mathrm{HbA}_{2} \geq 3,5$ memberikan nilai diagnostik yang paling baik untuk menentukan pembawa sifat talasemia $b(1,18)$. Pada penelitian ini diketahui bahwa dengan parameter $\mathrm{HBA}_{2} \geq$ $3,5 \%$ sensitivitasnya mencapai $93,5 \%$ untuk deteksi talasemia $6 . \mathrm{HbA}_{2}$ memiliki nilai sensitivitas dan spesifisitas yang baik sebagai alat diagnostik skrining carrier talasemia $\beta$ (19), namun beberapa peneliti menyarankan untuk tidak menggunakan $\mathrm{HbA}_{2}$ sebagai marker tunggal. Kombinasi nilai $\mathrm{MCV}, \mathrm{MCH}$ dan $\mathrm{HbA}_{2}$ sangat direkomendasikan sebagai marker awal deteksi dini carrier Talasemia $B(1,20)$.

Pemeriksaan $\mathrm{HBA}_{2}$ menjadi sangat penting dalam tahapan skrining pembawa sifat talasemia. Pemakaian parameter ini dapat menyaring probandus yang lolos dalam pemeriksaan indeks darah MCV dan MCH. Pada beberapa penelitian disebutkan bahwa probandus dengan MCV dan $\mathrm{MCH}$ yang rendah dapat menunjukkan nilai $\mathrm{HBA}_{2}$ yang normal. Pada kasus-kasus tersebut dimungkinkan probandus yang diperiksa tersebut adalah pembawa talasemia a (9). Beberapa kasus lain menunjukkan parameter $\mathrm{HBA}_{2} \geq 3,5 \%$ tetapi dengan indeks darah yang normal. Keadaan tersebut dapat terjadi pada kasus pembawa sifat talasemia yang baru saja mendapat transfusi akibat penyakit atau keadaan lainnya (21).

Jenis mutasi yang ditemukan pada penelitian ini tidak jauh berbeda dengan penemuan terhadap etnis Jawa lainnya. Mutasi IVS1 nt $5(\mathrm{G}<\mathrm{C})$ merupakan jenis mutasi yang terbanyak ditemukan, kemudian berturut adalah IVS1 nt 1 $(\mathrm{G}<\mathrm{T}$ ) dan HBE (kodon 26). Temuan ini masih sesuai dengan penelitian Iswari dkk yang menyatakan bahwa untuk etnis Jawa di dominasi oleh mutasi IVS $1 \mathrm{nt} \%(\mathrm{G}<\mathrm{C})(22)$. Jenis lain yang merupakan jenis mutasi yang cukup sering ditemukan di etnis jawa namun tidak ditemukan pada penelitian ini adalah jenis mutasi CD -35. Penemuan ini menunjukkan bahwa daerah Banyumas masih tergolong daerah dengan isolasi perkawinan yang cukup kuat. Tidak ditemukannnya mutasi lain menunjukkan tingkat mobilitas dan cross breeding di daerah ini masih sangat kecil. Dari kajian ini dapat disimpulkan bahwa sensitivitas dan spesifisitas indeks darah MCV dan $\mathrm{MCH}$ dapat dipakai sebagai perangkat awal skrining diagnosa karier talasemia. Prevalensi karier talasemia $B$ pada pendonor darah di Banyumas adalah $8 \%$ mutasi IVS1 nt5 sebagai jenis mutasi yang paling banyak ditemukan.

\section{UCAPAN TERIMA KASIH}

Penulis menyampaikan terima kasih kepada Health Professional Education Quality (HPEQ) Project Unsoed atas pendanaan penelitian ini.

traits in Yogyakarta Population. Dipresentasikan pada 11th International Conference on Thalassaemia and Haemoglobinophaties \& 13rd International TIF Conference for Thalassaemia Patients and Parents. Singapore; 8-11 Oktober 2008

4. Rujito L, Setyono J, dan Siswandari W. Data Penelitian Project Riset Unggulan Unsoed (RUKU) 2012. [Laporan]. Universitas Jenderal Soedirman, Purwokerto. 2012.

5. Weatherall DJ. Fortnightly Review: The Thalassaemias. British Medical Journal. 1997; 314(7095): 1675. 
6. Sin SY, Ghosh A, Tang LC, and Chan V. Ten Years Experience of Antenatal Mean Corpuscular Volume Screening and Prenatal Diagnosis for Talasemia in Hongkong. Journal of Obstetrics and Gynaecology Research. 2000; 26(3): 203-208.

7. Health Technology Assesment. Pencegahan Talasemia (Hasil Kajian HTA tahun 2009). Jakarta: Dirjen Bina Pelayanan Medik Kementerian Kesehatan Republik Indonesia; 2010.

8. Centers for Disease Contol and Prevention. Thalassemia. (Online). http://www.cdc.gov/ncbddd/ talasemia/indeks.html.

9. $\mathrm{Li} \mathrm{LY}$, Li Q, Song LL, et al. The value of $\mathrm{MCV}, \mathrm{MCH}$ and $H b A(2)$ in Laboratory Screening of Thalassemia. Zhonghua Fu Chan Ke Za Zhi. 2012; 47(2): 96-100.

10. Buckingham L. Molecular Diagnostics: Fundamentals, Methods and Clinical Applications. 2nd edition. Canada: FA Davis Company; 2011.

11. Mahadik CT. Experience With Multiplex ARMS (MARMS)-PCR for the Detection of Common BetaThalassemia Mutations in India. Cardiovascular \& Hematological Agents in Medicinal Chemistry. 2012; 10(1): 14-24.

12. Hernanda PY, Tursilowati L, Arkesteijn SG, et al. Towards a Prevention Program for Beta-Talasemia. The Molecular Spectrum in East Java, Indonesia. Hemoglobin. 2012; 36(1): 1-6.

13. Harteveld CL and Higgs DR. Alpha-Thalassaemia. Orphanet Journal of Rare Diseases. 2010; 5(1): 13.

14. Muncie HR and Campbell JS. Alpha and Beta Thalassemia. American Family Physician. 2009; 80(4): 339-344.

15. Shen C, Jiang YM, Shi H, et al. Evaluation of Indices in
Differentiation between Iron Deficiency Anemia and Beta-Talasemia Trait for Chinese Children. Journal of Pediatric Hematology/Oncology. 2010; 32(6): 218222.

16. Yong KN, Wadsworth D, Langlois S, Yong SL, and Wilson RD. Talasemia Carrier Screening and Prenatal Diagnosis among the British Columbia (Canada) Population of Chinese Descent. Clinical Genetics. 1999; 55(1): 20-25.

17. Weatherall DJ and JB Clegg. The Thalassaemia Syndromes. 4th edition. Oxford: Blackwell Science; 2008.

18. Weatherall DJ. Phenotype-Genotype Relationships in Monogenic Disease: Lessons from the Thalassaemias. Nature Reviews Genetics. 2001; 2(4): 245-55.

19. Vehapoglu A, Ozgurhan G, Demir AD, et al. Hematological Indices for Differential Diagnosis of Beta Thalassemia Trait and Iron Deficiency Anemia. Anemia. 2014; 2014: 7.

20. Dell'edera D, Epifania AA, Milazzo GN, et al. Identification of Patients with Defects in the Globin Genes. Journal of Prenatal Medicine. 2013; 7(4): 4750.

21. Singh SP and Gupta S. Molecular Pathogenesis and Clinical Variability of Homozygous Beta 0-Thalassemia in Populations of Jammu Region of J\&K State (India). Hematology. 2006; 11(4): 271-275.

22. Pramoonjago P, Harahap A, Taufani RA, Setianingsih I, Marzuki S, and Harahap A. Rapid Screening for the Most Common a Thalassaemia Mutations in South East Asia by PCR Based Restriction Fragment Length Polymorphism Analysis (PCR-RFLP). Journal of Medical Genetics. 1999; 36(12): 927-938 